\title{
MICRO AND MESOZOOPLANKTON COMPOSITION DURING WINTER IN USHUAIA AND GOLONDRINA BAYS (BEAGLE CHANNEL, ARGENTINA)*
}

\author{
Florencia Biancalana ${ }^{1}$; María Sonia Barría de Cao ${ }^{1,2}$ \& Mónica Susana Hoffmeyer ${ }^{1,3}$ \\ ${ }^{1}$ Instituto Argentino de Oceanografía (CONICET-UNS) \\ (Camino La Carrindanga km 7,5, B8000FWB Bahía Blanca, Argentina) \\ e-mail: biancaf@criba.edu.ar \\ ${ }^{2}$ Universidad Nacional del Sur, Departamento de Biología, Bioquímica y Farmacia \\ (San Juan 670, 8000 Bahía Blanca, Argentina) \\ ${ }^{3}$ Universidad Tecnológica Nacional, Facultad Regional Bahía Blanca \\ (11 de Abril 461, 8000 Bahía Blanca, Argentina)
}

\begin{abstract}
The current paper analyses the micro and mesozooplankton in Ushuaia and Golondrina Bays, the first research on these plankton fractions of these areas in wintertime (August 2004). The number of microzooplankton and mesozooplankton taxa was higher in Ushuaia Bay than in Golondrina Bay. Aloricate ciliates predominated over tintinnids in microzooplankton and holoplankton over meroplankton in mesozooplankton in both bays. Ctenocalanus citer, Drepanopus forcipatus and Clausocalanus brevipes presented the highest frequency of occurrence. Among the meroplankton, Halicarcinus planatus and Munida gregaria were the most frequent decapod larvae in both bays. The distribution of the different sampling station groups of microzooplankton and mesozooplankton as determined by cluster analysis suggests the influence of natural conditions in each bay and anthropogenic environmental differences between the two bays.
\end{abstract}

\section{RESUMO}

Este trabalho analisa o micro e o mesozooplâncton das Baías Ushuaia e Golondrina, constituindo a primeira pesquisa realizada nessas áreas sobre estas frações do plâncton no inverno (agosto 2004). O número dos taxa do microzooplâncton e do mesozooplâncton foi mais elevado na Baía Ushuaia do que na Baía Golondrina. Os ciliados aloricados foram dominantes sobre os tintinídeos, enquanto que no mesozooplâncton o holoplâncton foi dominante nas duas baías. Ctenocalamus citer, Drepanopus forcipatus e Clausocalamus brevipes foram as espécies mais freqüentes. No meroplâncton, Halicarnus planatus e Munida gregaria foram as larvas de decápodes mais freqüentes em ambos os locais. Os diferentes grupos de estações formados em função do microzooplâncton e do mesozooplânkton, e detectados na análise de agrupamento, sugerem a influência de condições naturais em cada baía e de diferenças ambientais antropogénicas entre as duas baías.

Descriptors: Microzooplankton, Mesozooplankton, Ushuaia Bay, Golondrina Bay. Descritores: Microzooplâncton, Mesozooplâncton, Baía Ushuaia, Baía Golondrina.

\section{INTRODUCTION}

To our knowledge, there are no previous reports available in the literature on the taxonomic composition and other aspects of microzooplankton of the Ushuaia and Golondrina Bays, in the Beagle

Channel, Argentina. Furthermore, data on the mesozooplankton composition and overall bioecological conditions in these bays are scarce. Defren-

(*) Paper presented at the $2^{\text {nd }}$ Brazilian Congress of Oceanography, on 09-12 October 2005. Vitória, Brazil.
Jackson et al. (1999); Sabatini et al. (2001) and Thatje et al. (2003) undertook studies on mesozooplankton and meroplankton in the Beagle Channel. Thatje et al. (2003) reported differences in the occurrence and distribution of meroplankton organisms between deep and shallow zones of the Magellan region and Beagle Channel in November 1994. Differences in the abundance of holoplankton and meroplankton fractions in the Magellan region were also found for the same period (Defren-Jackson et al., 1999). Changes in the number, abundance and biomass of mesozooplankton were observed between spring and 
autumn 1996 in southern Patagonian and in eastern areas of the Beagle Channel (Sabatini et al., 2001). In recent pioneering research Fernández Severini \& Hoffmeyer (2005) studied the summertime (January 2001) composition, abundance and structure of mesozooplankton in Ushuaia and Golondrina Bays, reporting assemblages with differing composition apparently linked to distinct environmental conditions.in the bays.

The purpose of the present study is to analyse the composition of micro and mesozooplankton in Ushuaia and Golondrina Bays in August 2004.

\section{Study Area}

The Ushuaia Bay (UB) and Golondrina Bay (GB) are located on the northern coast of the Beagle Channel (54 $4^{\circ} 79^{\prime} \mathrm{S}-68^{\circ} 22^{\prime} \mathrm{W}$ and $54^{\circ} 85^{\prime}$ S-68 $36^{\circ} \mathrm{W}$, respectively), each one showing different hydrological features. The depth in UB ranges from 6 to $30 \mathrm{~m}$ in some western sectors, reaching up to $100-170 \mathrm{~m}$ in the East of the bay, close to the Beagle Channel. GB is shallower than UB, reaching depths of $20 \mathrm{~m}$ in zones near to the Beagle Channel (Comoglio, 1994). The two bays also differ in the type of bottom, UB displaying a consolidated soft-bottom surface with stones and shells whereas GB has a soft bottom, less consolidated than that of UB (Comoglio, 1994; Amín, 1995). Balestrini et al. (1998) reported currents with velocities of 5.5 to $16.3 \mathrm{~cm} / \mathrm{seg}$ in UB and of 0.6 $\mathrm{cm} / \mathrm{seg}$ in BG.

\section{Materials AND Methods}

Micro and mesozooplankton samples were collected from 15 stations in UB and 7 stations in GB on August 26, 2004 (Fig. 1). The microzooplankton was sampled from the surface and bottom using a Van Dorn bottle and through hauls with a $30 \mu \mathrm{m}$-mesh plankton net. Samples were preserved in Lugol solution and observed under a Zeiss contrast-phase light microscope. Strombidid ciliates were identified according to Maeda \& Carey (1985) and tintinnids according to the morphometric characteristics of loricae after Kofoid \& Campbell (1929). The mesozooplankton was extracted using a $200 \mu \mathrm{m}$-mesh net by means of oblique hauls from near the bottom up to the surface, aboard a motor boat at a speed of 2 knots during 5 min. Samples were preserved in $4 \%$ formalin (Boltovskoy, 1981). The mesozooplankton organisms were identified to the lowest possible taxonomic level under a Wild M5 stereomicroscope, using the appropriate literature (Heron \& Bowman, 1971; Lang, 1975; Bradford et al., 1988; Hulsemann, 1991; Mazzocchi et al., 1995; Boltovskoy, 1999).
Frequency of occurrence was calculated taking into account the number of stations in which each taxon was present. Cluster analysis of samples from both bays was carried out to obtain sampling station groups (Clarke \& Warwick, 1994). Taxa presence-absence data, the qualitative Bray-Curtis similarity coefficient and group average linking were applied (PRIMER E package). In the case of microzooplankton, data of presence-absence at each sampling station were considered independently of the sampled layer (surface or bottom). Temperature, salinity and chlorophyll $a$ seasonal data of both bays were published apart (Gil et al., 2006). In this study we used some data of these winter variables with the authors' permission.

\section{Results}

Number of Taxa and Frequency of Occurrence

Microzooplankton in UB was made up of 27 taxa and in GB of only nine (Table 1, Fig. 2A, B). UB showed a higher number of taxa than GB. The highest number of taxa (15) was recorded at station 1 in UB. Ciliates, mainly aloricate ciliates, predominated in both bays, the Strombidiidae family being the most numerous with nine species (30\% of the taxa present). Tintinnids were scarcely represented.

Forty-five mesozooplankton taxa were observed in UB and 30 in GB. Only 27 were common to both bays (Fig. 2A, B; Table 2). As in the case of microzooplankton, the number of taxa in UB was clearly higher than in GB. In UB, the highest number of taxa (23 and 25) was recorded at stations 4 and 13, respectively. The lowest number (9) was observed at station 2. In GB, the highest number of taxa was 19 at station 18 and the lowest 21 at station 6 .

Adventitious forms within overall mesozooplankton showed the highest percentage in both bays (44\% UB-47\% GB). The holoplankton fraction (31\% UB-30\% GB) predominated over meroplankton (24\% UB, 23\% GB) (Fig. 3A, B). Among the holoplankton, Ctenocalanus citer showed the highest frequency (100\%, in UB and GB) followed by Drepanopus forcipatus and Clausocalanus brevipes ( $87 \%$ and $73 \%$ in UB and $86 \%$ in both cases for GB) (Table 2). Oithona similis showed the same frequency as $C$. citer in UB (100\%) and $86 \%$ in BG. Although Acartia tonsa presented the highest frequency in UB (93\%), in GB it played only a minor role, not reaching $43 \%$. The only decapod larvae featuring prominently among the meroplankton were those of Halicarcinus planatus (93\% in UB and $100 \%$ in GB) and Munida gregaria (93\% in UB and $86 \%$ in GB). Porcellidium rubrum (53\% in UB and $57 \%$ in GB), Tisbe varians (53\% in UB and $43 \%$ in GB) and Ostracoda (53\% in UB and $43 \%$ in GB) were the most frequent adventitious fraction occurring in both bays. 


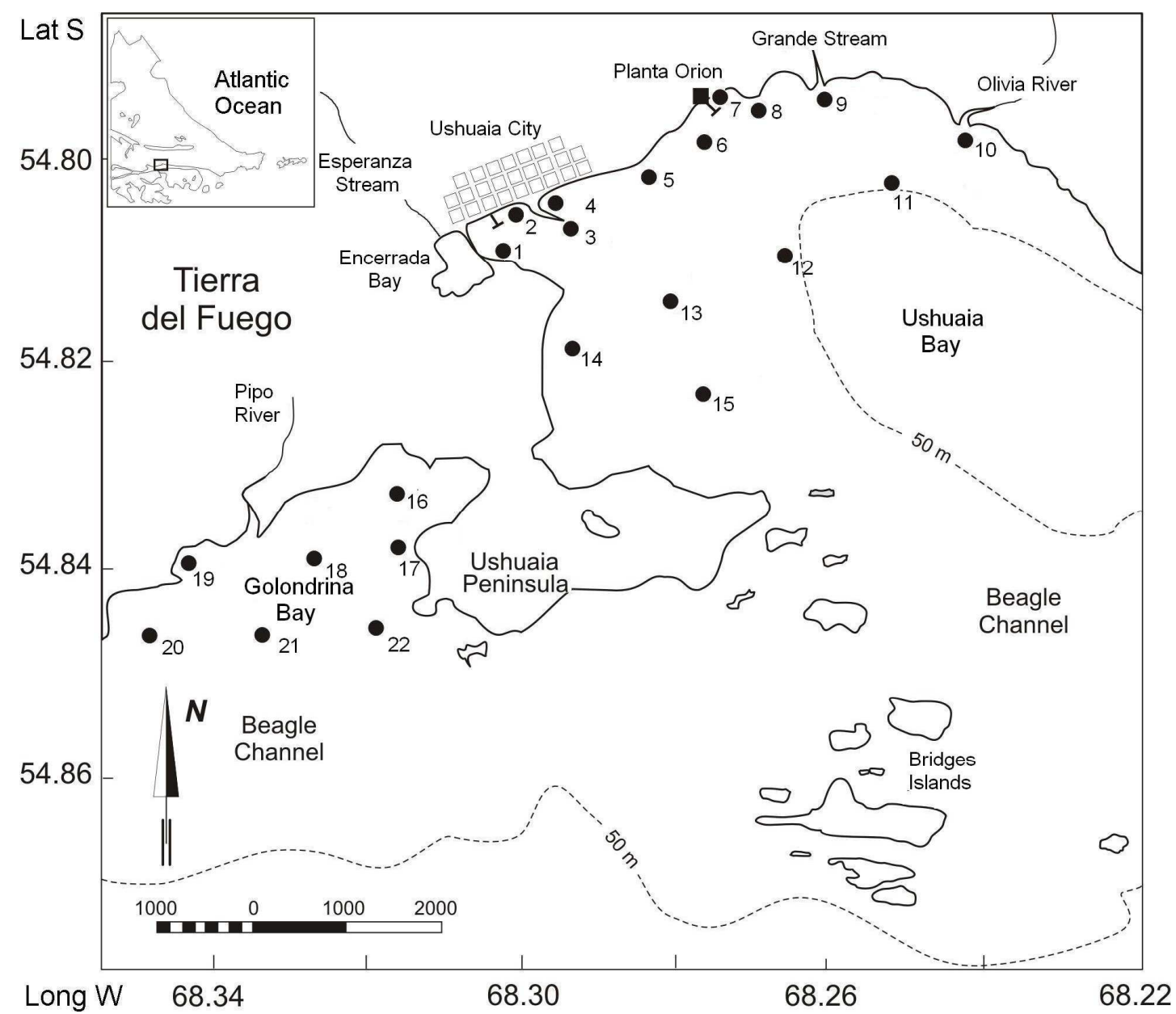

Fig. 1. Location of sampling stations in Ushuaia and Golondrina Bays.

Cluster Analysis

Based on the results of the cluster analysis with a similarity level of $32 \%$, it was possible to differentiate four main groups in UB (Fig. 4A; Table 3). The first group (G1) comprised samples from stations 2, 4 and 12. The second group (G2) comprised samples 1, 6, 7 and 8; the third group (G3) corresponded to stations $3,9,10,11$ and 15 ; and the fourth (G4) to stations 5, 13 and 14. These associations differred on the presence of certain species of aloricate ciliates. The main characteristic of G1 was the presence of three species of Strombidium (sp 1, sp2 and sp3) in all samples; of G2, the presence of Strobilidium sp.; of G3, the presence of
Strombidium conicum and the scarce representation of the previously mentioned species; and in G4 the common feature was the presence of Strombidium sulcatum. Most of the stations of the first and second groups were located in the inner part of the bay. In the case of GB, three associations were observed with an arbitrary $32 \%$ similarity, there being no common species among the samples (Fig. 4B; Table 3). G1 was made up of samples 16, 17, 19 and 21 and the common feature was the presence of Strombidium conicum. G2 consisted of only one sample (20), characterized by the presence of $S$. aff. sulcatum, Strombidium sp.3, Strombidium sp.4 and Tintinnopsis parva. G3 was made up of samples 18 and 22 with the presence of Tintinnopsis glans in common. 
Table 1. Frecuency of occurrence (FO \%) of microzooplankton taxa in Ushuaia and Golondrina Bays. x: presence of taxa at surface. *: presence of taxa at bottom.

\begin{tabular}{|c|c|c|c|c|c|c|c|c|c|c|c|c|c|c|c|c|c|c|}
\hline & \multirow[b]{2}{*}{ Taxa } & \multicolumn{13}{|c|}{ Ushuaia Bay } & \multicolumn{4}{|c|}{ Golondrina Bay } \\
\hline & & 12 & 23 & 4 & 5 & 6 & 78 & 9 & 10 & 11 & 121 & 1314 & 15 & FO\% 16 & 1617 & 181920 & 202122 & 2 FO\% \\
\hline \multirow{18}{*}{ Aloricate Ciliates } & Strombidium conicum & * & $\mathrm{x}$ & & $\mathrm{x}$ & * & $*$ & $*$ & * & $\mathrm{x}$ & & $\mathrm{x}$ & $\mathrm{x}$ & $67 *$ & $x^{*}$ & $x^{*}$ & $\mathrm{x}$ & 57 \\
\hline & S. aff. sulcatum & & & & $\mathrm{x}$ & & & & & & $* x$ & $\mathrm{x} *$ & & 27 & & $\mathrm{x}$ & $\mathrm{x}$ & 14 \\
\hline & S. aff. acutum & & $\mathrm{x}$ & & & & & & & $\mathrm{x}$ & & & & 13 & & & & 0 \\
\hline & S. aff. minutum & & & & & & & & & & & & $\mathrm{x}$ & 7 & & & & \\
\hline & S. aff. reticulatum & & & & & & & & & & & & $\mathrm{x}$ & 7 & & & & 0 \\
\hline & Strombidium sp. 1 & ** $*$ & $*$ & * & & $x^{*}$ & * & * & & & $x \quad x$ & $\mathrm{x}$ & & 47 & & $\mathrm{x}$ & & 14 \\
\hline & Strombidium sp. 2 & & * & & & $\mathrm{x}$ & $\mathrm{x}$ & & & $\mathrm{x}$ & $*$ & & & 33 & & & & 0 \\
\hline & Strombidium sp. 3 & & & & & & & & & & * & & & 7 & & $\mathrm{x}$ & $\mathrm{k}$ & 14 \\
\hline & Strombidium sp. 4 & * & & & & & ** * & * & & & & & & 20 & & $\mathrm{x}$ & $\mathrm{k}$ & 14 \\
\hline & Strombidinopsis sp. 1 & * & & & & & & $*$ & & & & & & 13 & & & & 0 \\
\hline & Strombidinopsis sp. 2 & $\mathrm{x}$ & & & & & & & & & & & & 7 & & & & 0 \\
\hline & Strobilidium sp. & * & & & & $\mathrm{x}$ & $\mathrm{x} *$ & * & & & & & & 27 & & & & 0 \\
\hline & Cyrtostrombidium sp. & * & & & & & $\mathrm{x}$ & & & & & & & 13 & & & & 0 \\
\hline & Laboea sp. & & & & & * & * & * & & & & & & 13 & & & & 0 \\
\hline & Leegardiella sp. & & & & & & & & & & $\mathrm{x}$ & & & 7 & & & & 0 \\
\hline & Mesodinium aff. acarus & & & * & & & & & & & & & & 7 & & & & 0 \\
\hline & Mesodinium sp. & & & * & & & & & & & & & & 7 & & & & 0 \\
\hline & Holophrya sp. & & & & & & & $*$ & & & & & & 7 & & & & 0 \\
\hline \multirow{8}{*}{ Tintinnids } & Tintinnopsis brasiliensis & * & & & & & & & & & & * & & 13 & & & & 0 \\
\hline & Tintinnopsis glans & & & & & & & & & & & & & 0 & & $\mathrm{x}$ & $\mathrm{x}$ & 28 \\
\hline & Tintinnopsis gracilis & * & & & & & & & & & & & & 7 & & & & 0 \\
\hline & Tintinnopsis parvula & * & & & & & & & & & & & & 7 & & & & 0 \\
\hline & Tintinnopsis parva & & & & & & & & & & & & & 0 & $\mathrm{x}$ & & & 14 \\
\hline & Tintinnopsis sp. & & & & & & & & & $\mathrm{x}$ & & & & 7 & & & & 0 \\
\hline & Codonellopsis pusilla & * & & $\mathrm{x}$ & $\mathrm{x}$ & & & & * & & & & & 27 & & $\mathrm{x}$ & & 14 \\
\hline & Undella aff. claparedei & $*$ & & & & & & & & & & & & 7 & & & & 0 \\
\hline Foraminifers & Globorotalia sp. & * & & & & & & & & & & & & 7 & & & & 0 \\
\hline \multirow[t]{2}{*}{ Micrometazoans } & Rotatoria aff. Brachionus & $*$ & & & & & & & & & & & & 7 & & & & 0 \\
\hline & Nauplii stages & ** * & * & & & * & & & & & & & & 20 & & $\mathrm{x}$ & & 14 \\
\hline
\end{tabular}

The cluster analysis for mesozooplankton in both bays (Fig. 5A, B) determined two groups at a $50 \%$ similarity level. In UB, most samples $(3,4,5,6$, $7,8,9,10,11,1,2,13,14$ and 15$)$ fell within the first group (G1) whereas the second group (G2) was made up of samples 1 and 2 only (Fig. 5A; Table 4). The main feature of G1 was the presence of Clausocalanus brevipes, Drepanopus forcipatus and Gastropoda larvae. G2 differed from G1 in the absence of these latter taxa and the $100 \%$ frequency of occurrence of Eurytemora americana. In GB, G1 was made up of samples 16, 18, 19, 20, 21, 22 and G2 of sample 17 only (Fig. 5B; Table 4).The difference between G1 and G2 was the presence of Clausocalanus brevipes,
Drepanopus forcipatus, Oithona similis and larvae of Munida gregaria in the former.

\section{Environmental Data}

The mean temperature in UB was $5.24 \mathrm{C}^{\circ}$ and the range 4.10 to $5.60 \mathrm{C}^{\mathrm{o}}$. In $\mathrm{GB}$ the mean temperature was $5.27 \mathrm{C}^{\circ}$, range between 4.50 and 5.68 $\mathrm{C}^{\circ}$. Mean salinity in UB was 31.24 ups and the range was 30.58 - 31.44 ups; and in GB 30.95 ups and 30.08-31.19 ups, respectively. The mean chlorophyll $a$ concentration and range were $0.71 \mathrm{mg} \mathrm{m}^{-3}$ and 0.23 at $2.33 \mathrm{mg} \mathrm{m}^{-3}$ in $\mathrm{UB}$, and $0.31 \mathrm{mg} \mathrm{m}^{-3}$ and 0.07 at 0.68 $\mathrm{mg} \mathrm{m}^{-3}$ in GB, respectively (Fig. 6). 

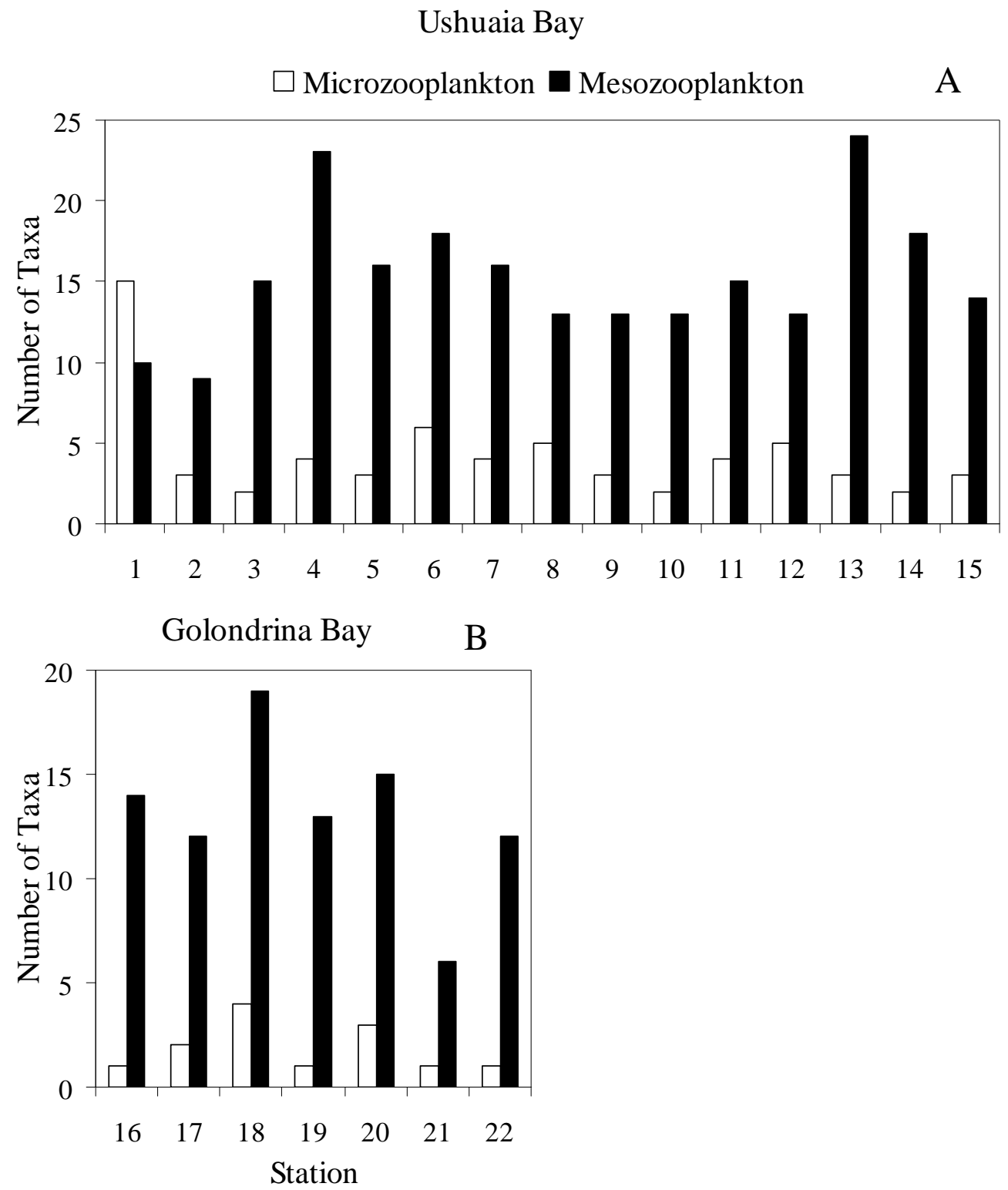

Fig. 2.Taxa number of micro and meszooplankton in Ushuaia (A) and Golondrina (B) Bays. 
Table 2. Frecuency of ocurrence (FO \%) of mesozooplankton taxa in Ushuaia and Golondrina Bays. x: presence of taxa at surface.

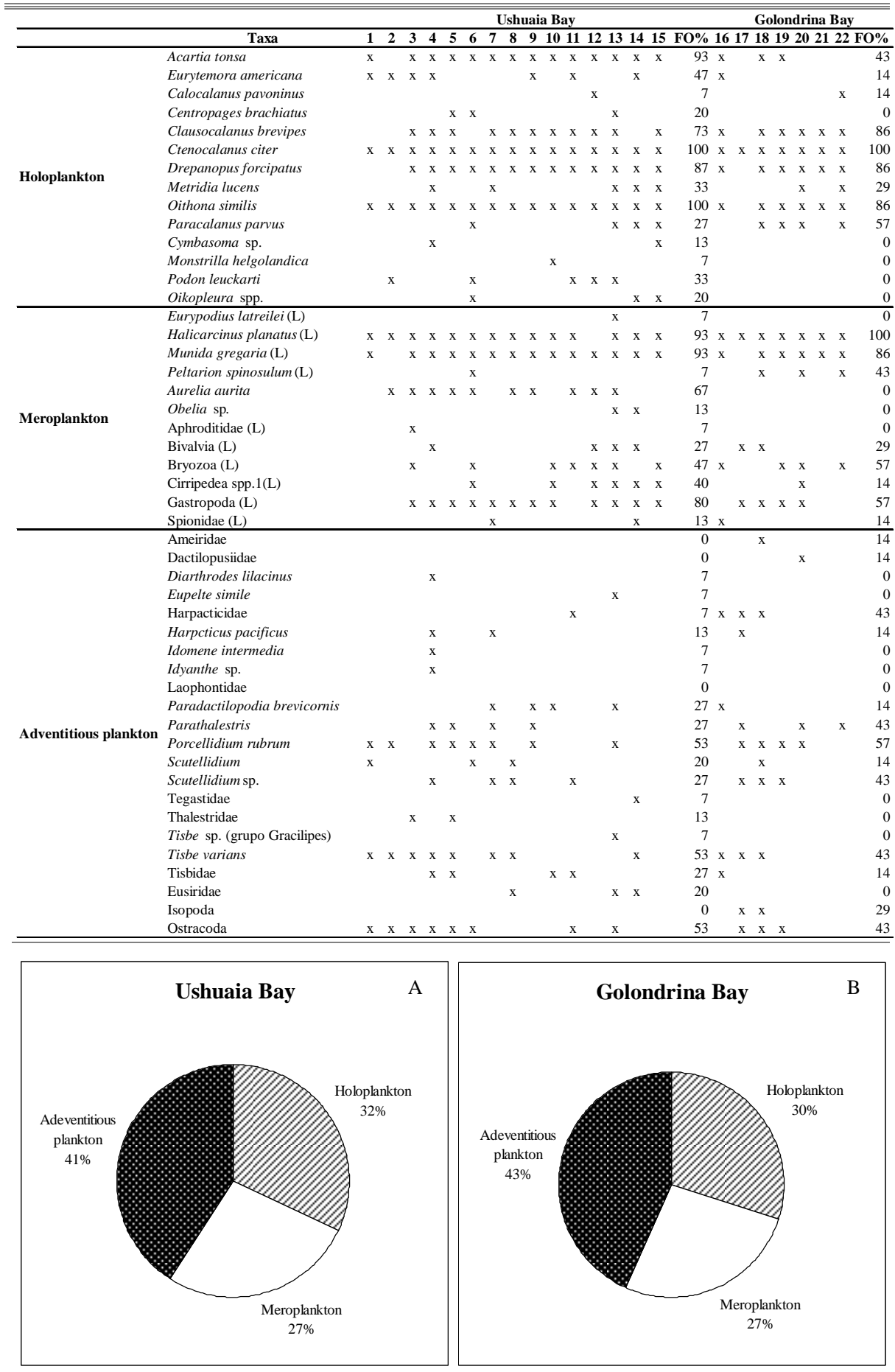

Fig. 3. Percentage of holoplankton, meroplankton and adventitious plankton in the mesozooplankton of Ushuaia (A) and Golondrina (B) Bays. 

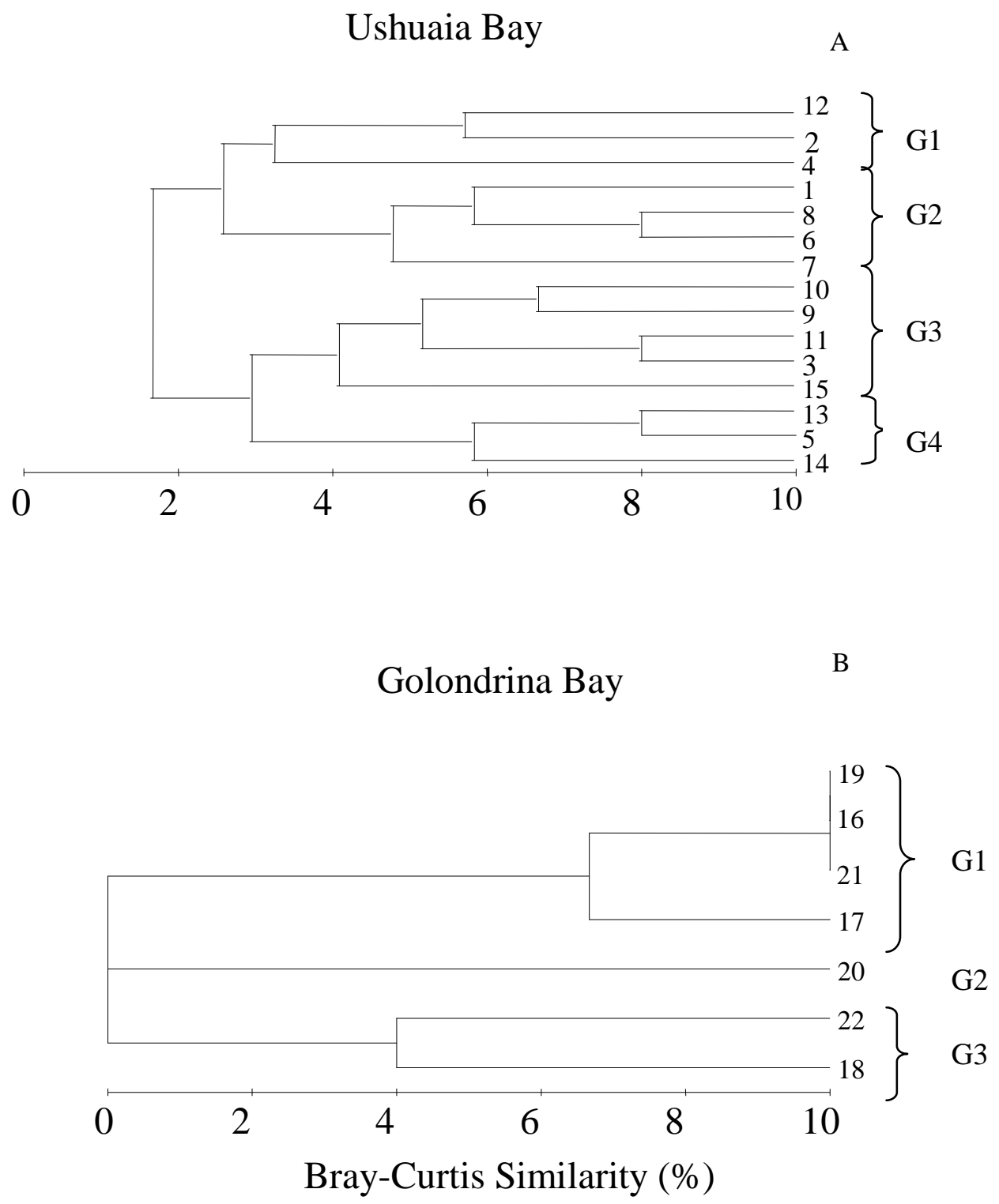

Fig. 4. Cluster showing microzooplankton sample groups for Ushuaia (A) and Golondrina (B) Bays. 


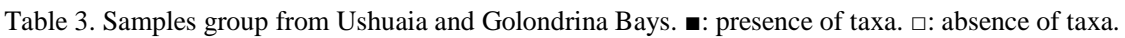

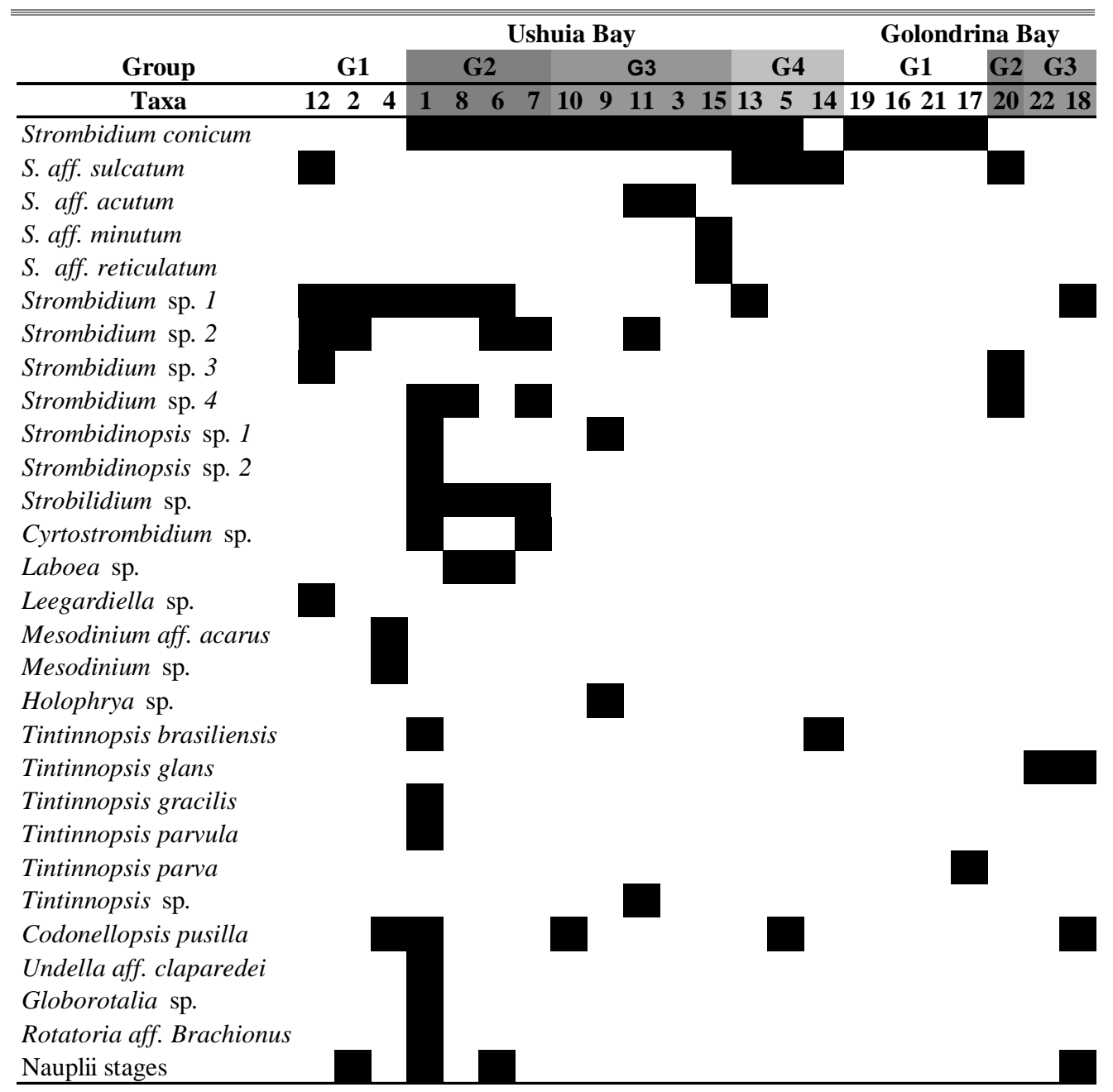

\section{DisCUSSION}

Though the data collected in the present study were merely qualitative, they constitute the first report on the composition and occurrence of micro and mesozooplankton in Ushuaia and Golondrina Bays in wintertime.

Owing to the dominance of ciliates aloricate ciliates as well as tintinnids- the composition of microzooplankton in the two studied bays during the winter was similar to that observed in other coastal areas of Argentina such as Bahía Blanca Estuary (Barría de Cao et al., 1997; Pettigrosso et al., 1997), where the genus Strombidium also showed the highest number of species among the aloricate ciliates.
Tintinnids showed a higher number of taxa (11 spp.) in Bahía Blanca Estuary than in the Ushuaia and Golondrina Bays, where tintinnids seem to be less important, at least during the winter.

The cluster analysis showed distinct sample groups in the two bays, each linked to the presence of particular species. One of the groups clearly corresponded mainly to stations of the inner zone and the other to those of the outer zone. In Ushuaia Bay the groups seem to be clearly differentiated by the effect of certain environmental factors on the presence or absence of species. G1 and G2 comprised mainly samples from stations located in the inner bay; and particularly G2 was made up of samples located at stations very close to the coast, near waste water and 


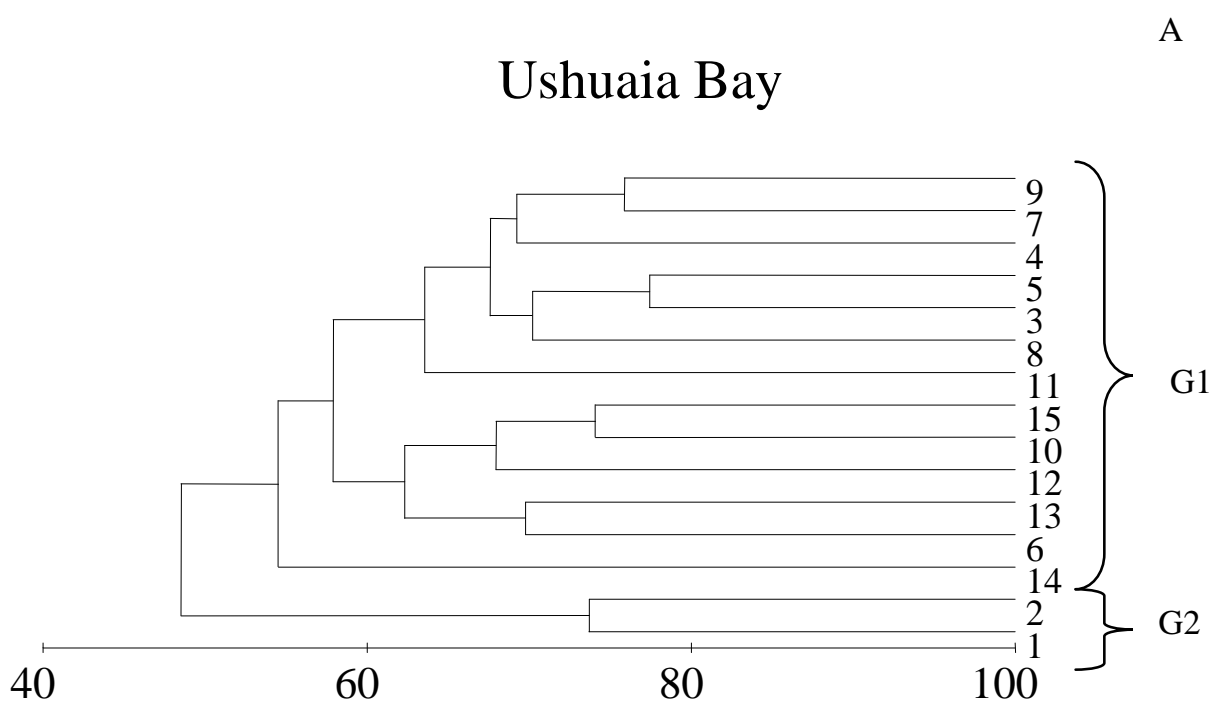

B

\section{Golondrina Bay}

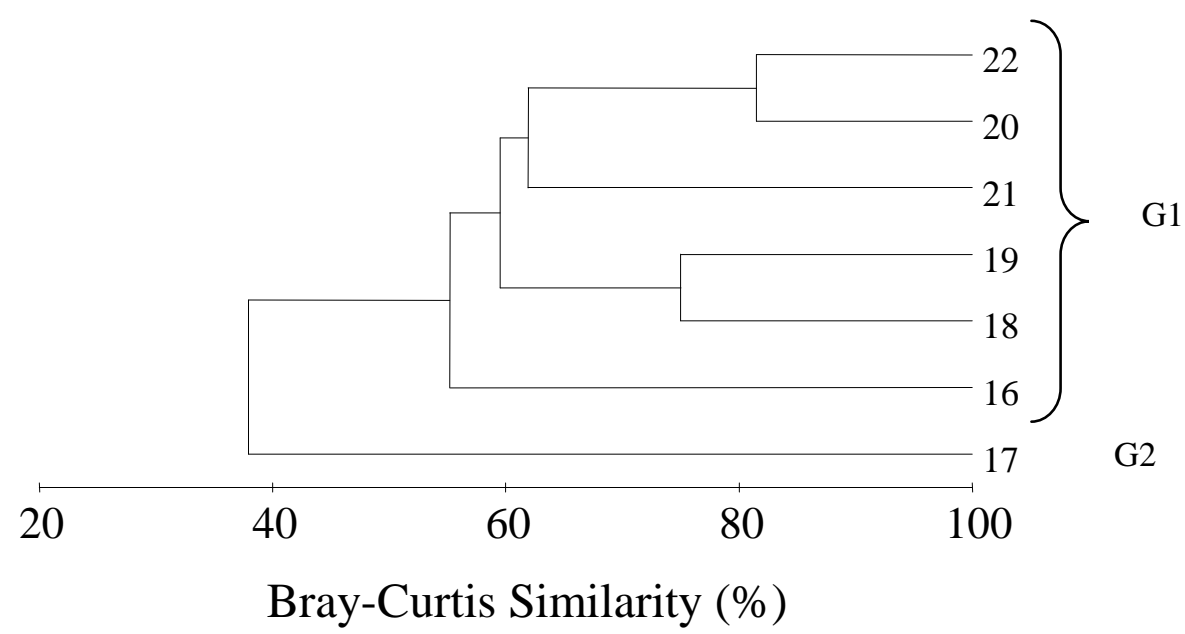

Fig. 5. Cluster showing mesozooplankton sample groups for Ushuaia (A) and Golondrina (B) Bays. 
Table 4. Mesozooplankton sample groups from Ushuaia and Golondrina Bays. $\mathbf{m}$ : presence of taxa $\square$ : absence of taxa.

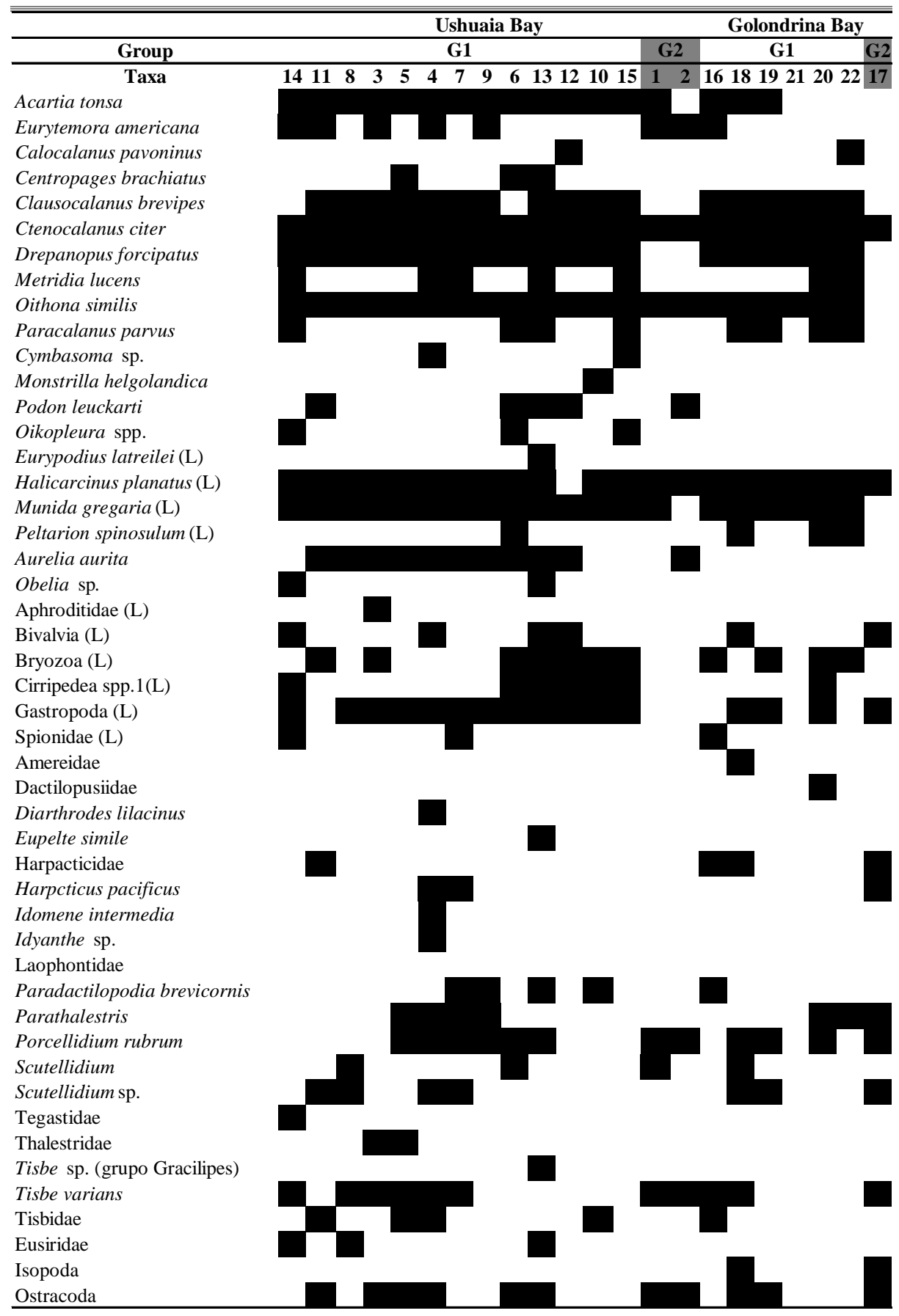


industrial effluent discharge zones. Some tightly associated stations such as 9 and 10 in G3 were located at a zone influenced by freshwater discharge despite the fact that salinity values recorded were not low, due to the lack of defrost fluxes as well as to wind or tide effects. Temperature and salinity values did not differ significantly, whereas the chlorophyll $a$ concentration showed a peak at station 2 in Ushuaia Bay. Ciliates were very scarce at this station though a significant number of nauplii stages was encountered. The higher chlorophyll $a$ values indicate a higher phytoplankton biomass possibly owing to the presence of large phytoplankton species unsuitable as a source of food for ciliates. As in Ushuaia Bay, the three sample groups (G1, G2 and G3) formed in GB could be defined by the effect of certain environmental factors on the presence or absence of species.

Concerning the mesozooplankton, number of taxa observed in UB was higher than that in GB during the winter. Fernández Severini \& Hoffmeyer (2005) reported the same finding for summertime, in January 2001, possibly owing to the higher impact of anthropogenic factors in UB. On the other hand, copepods were the main constituents of the holoplankton in both bays, in agreement with the study carried out by Defren-Jackson et al. (1999) in the Magellan region and western Beagle Channel during the "Victor Hensen" campaign in November 1994. C. citer, D. forcipatus, $C$. brevipes and $O$. similis, which showed the highest frequency of occurrence in both bays, are typical copepods from cold coastal areas of South America and Antarctica (Fernández Severini \& Hoffmeyer, 2005). Sabatini et al. (2001) reported the presence of the copepods $D$. forcipatus and $C$. brevipes in the eastern zone of the Beagle Channel and southern Patagonian coasts, the former being the main copepod in autumn and spring and the latter being present only in autumn.

The copepods Acartia tonsa, Eurytemora americana (an exotic species) and Tisbe varians were observed in UB and GB during this study. They were also reported in both bays during the summer (Fernández Severini \& Hoffmeyer, 2005) and had previously been observed in the Bahía Blanca Estuary (Hoffmeyer, 1983; 1994; 2004). These species are typical small copepods from temperate and cold-temperate estuarine-coastal areas in the Northern Hemisphere with anthropogenic influence and maritime activities (Conover, 1956; Miller, 1983).

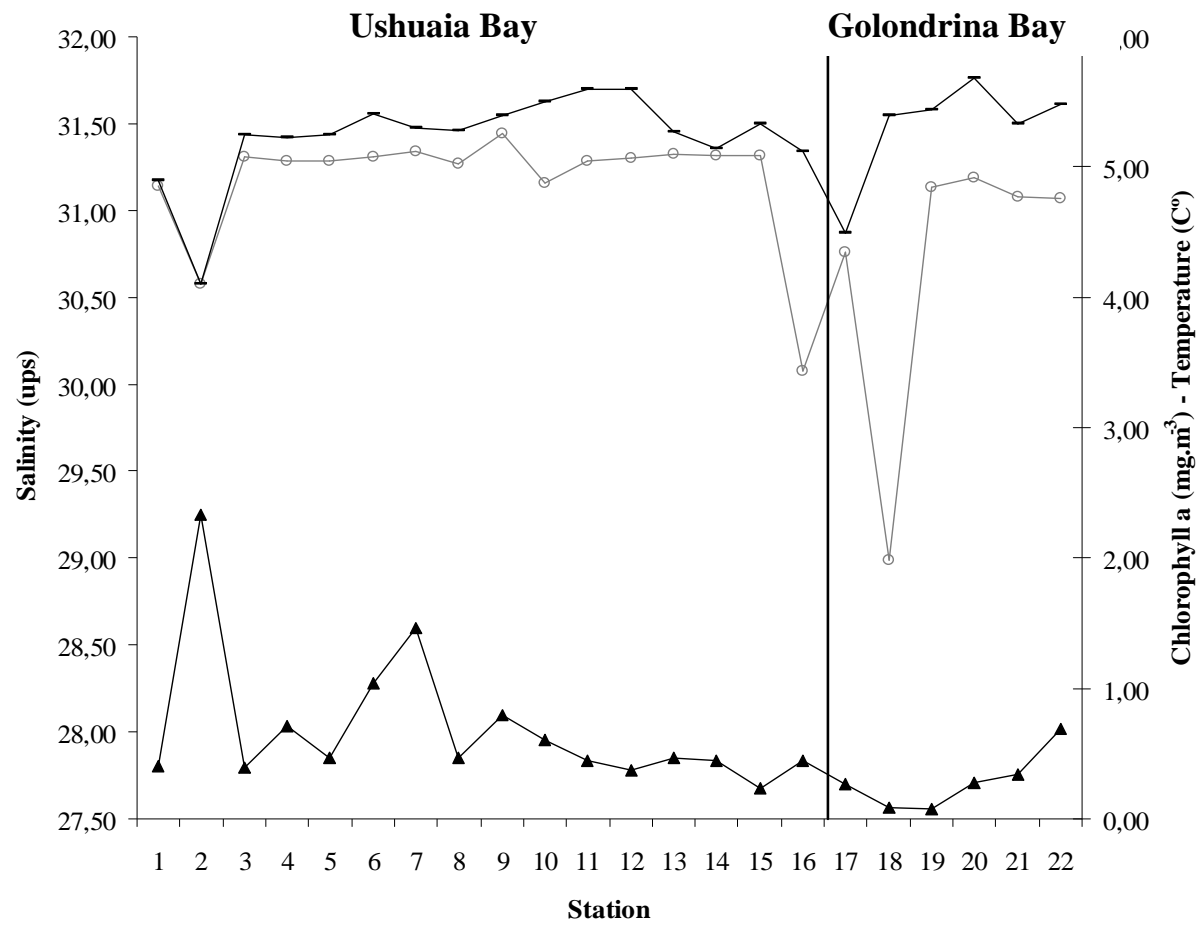

Fig. 6. Mean temperature (-), salinity (o) and Chlorophyll $a$ (A) (after Gil et al., 2006) variation in Ushuaia and Golondrina Bays. 
The main taxa among the meroplankton of both bays were Halicarcinus planatus and Munida gregaria, Eurypodius latreillii and Peltarion spinosolum being of lower frequency. Lovrich (1999) reported the presence of these taxa in the Beagle Channel during August. Thatje et al. (2003) observed 17 taxa of decapod larvae in the Magellan region and Beagle Channel (November 1994), including the taxa found in the present study. Likewise in the present study, Thatje et al. (2003) observed the presence of Bryozoa, Cirripedia, Bivalvia, Gastropoda and Cnidaria larvae in zooplankton samples obtained through vertical hauls from the bottom to the surface.

Several harpacticoid copepods, isopods and amphipods constituting adventitious planktonic forms (i.e. those belonging to benthos or some other community that moves to the water column, also known as tychoplankton) were frequently observed in the present study. These groups were found in strong association with dense kelps dominated by Macrocystis pirifera, particularly located in the shallowest areas of both bays up to approximately 15 $\mathrm{m}$ depth, in agreement with the findings by Pallares (1968) for Deseado Port (Santa Cruz, Argentina) and Fernández Severini \& Hoffmeyer (2005) in these same bays during the summer.

The cluster analysis results of the present study are similar to those obtained by Fernández Severini \& Hoffmeyer (2005) during the summer. The precise reasons for the formation of different sample groups in the two bays are not clear, though this fact may reflect the differences in the environmental conditions and water quality. In Ushuaia Bay, the formation of G1, constituted by coastal stations where the anthropogenic impact is greater and by some stations less linked to the coast, could be related to the anticlockwise water current flowing into the bay from the Beagle Channel (Balestrini et al., 1998). G2 comprises just two coastal station samples (stations 1 and 2) in which the occurrence of Eurytemora americana $(100 \%)$ is particularly significant. This group is located in the area of the Nautico Club close to Encerrada Bay, which receives discharges from various domestic sources and defrost fluxes especially during spring. Furthermore, station 2 presented the highest mean concentration of chlorophyll $a$ and the lowest temperature and salinity values, which may explain the presence of E. americana in this group. Recently, Biancalana \& Torres (2006) observed the presence of Eurytemora americana in water flowing from Encerrada Bay with temperatures between 8.8 and $11.7^{\circ} \mathrm{C}$ and salinities between 1.44 and 22.5 ups in December 2004 and March September 2005.

In Golondrina Bay, most of the samples (except those from station 17, which corresponded to
G2) belonged to G1. G2 differed from G1 in the absence of $C$. brevipes, $D$. forcipatus, $O$. similis, typical copepods from Channel Beagle waters and Munida gregaria larvae. Station 17 is the shallowest station in Golondrina Bay (1.5 m deep) adjoining a waste water discharge zone, thus reducing the salinity values and possibly influencing taxa distribution.

At a first glance, the relative abundance of mesozooplankton observed in the present study was lower than that observed in summer by Fernandez Severini \& Hoffmeyer (2005), and qualitative results clearly demonstrate that in winter as in summer, the mesozooplankton displays a different spatial pattern in both bays. Also, the microzooplankton in winter seems to show a similar spatial pattern which is evidenced through changes in composition as well as in numbers of micro- and meso-zooplankton taxa. Such differences could be a response to different abiotic and biotic conditions in both bays: circulation of water (Balestrini, 1998), chemical and physical traits (Esteves \& Amín, 2001), depths (Isla, 1999), density and diversity of benthos (Diez et al., 2005), and anthropogenic pressure (Amín et al., 1995).

\section{ACKNOWLEDGEMENTS}

We are grateful to the staff of Centro Austral de Investigaciones Científicas (CONICET) and particularly to those colleagues who actively collaborated in collecting data and samples during the sampling period. Funds were provided by FONCYTANPCyT (PICTR090/2002).

\section{REFERENCES}

Amín, O.; Andrade, S.; Ferrer, L. \& Marcovecchio, J. 1995. Heavy metal concentration in litteral sediments from the Beagle Channel, Tierra del Fuego, Argentina. Environ. Monit. Assessement., 41:219-231. Esta citado en la pag.12.

Balestrini, C.; Manzella, G. \& Lovrich, G. A. 1998 Simulación de corrientes en el Canal Beagle y Bahía Ushuaia, mediante un modelo bidimensional. Serv. Hidr. Naval. Dep. Oceanog. Infme técn., 98:1-58.

Barría de Cao, M. S.; Pettigrosso, R. \& Popovich, C. A. 1997. Planktonic ciliates during a phytoplankton bloom in Bahía Blanca estuary, Argentina. II. Tintinnids. Oebalia, 23:21-31.

Biancalana, F. \& Torres, A. I. 2006. Composición del mesozooplancton y su relación con los parámetros ambientales en la Bahía Encerrada. VI Jornadas Nacionales de Ciencias del Mar and XIV Coloquio Argentino de Oceanografía. Puerto Madryn - Argentina. December $04^{\text {th }}-8^{\text {th }}$. Abstract Book, p. 206.

Boltovskoy, D. 1981. Características biológicas del Atlántico Sudoccidental. In: Boltovskoy, D., ed. Atlas del zooplancton de Atlántico Sudoccidental y métodos de trabajo con el zooplancton marino. Mar del Plata, Publ. esp. INIDEP:239-248. 
Boltovskoy, D. 1999. South Atlantic zooplankton. Leiden: Blackhuys Publs. v.1,2. 1705 p.

Bradford, J. M.; Ohman, M. D. \& Jillett, J. B. 1988. Larval morphology and development of Neocalanus tonsus, Calanoides macrocarinatus, and Calanus australis (Copepoda: Calanoida) in the laboratory. N.Z. Jl mar. Freshwat. Res., 22:301-320.

Clarke, K. R. \& Warwick, R. M. 1994. Change in marine communities: An approach to statistical analysis and interpretation. Cambridge, U.K.: Natural Enviroment Research Council.

Conover, R. 1956. VI - Biology of Acartia clausi and A. tonsa. Bull. Binghan oceanogr. Colln., 15:156-233.

Defren-Jackson, K.; Schnack-Schiel, S. B. \& Richter, C. 1999. Mesozooplankton communities in the Magellan region. Sci. Mar., 63(Suppl.1):43-50.

Diez, M.; Romero, M.; Tapella, F. \& Obenat, S. 2005. Distribución batimétrica, espacial y temporal del macrozoobentos del Canal Beagle, Tierra del Fuego, Argentina. In: XXV Congreso del Ciencias del Mar de Chile and XI Congreso Latinoamericano del Ciencias de Mar, Viña del Mar, Chile. Expanded Abstract. In: Exposiciones Poster (PDF file). http://www.colacmar.cl.

Esteves, J. L. \& Amín, O. 2001. Evaluación de la Contaminación Urbana de las Bahías de Ushuaia, Encerrada y Golondrina (Provincia de Tierra del Fuego, Antártica e Islas del Atlántico Sud). Consolidación e Implantación del Plan de la Zona Costera Patagónica (PMZCP) - ARG/02/G31 - GEF/PNUD. CDROM.

Fernández Severini, M. D. \& Hoffmeyer, M. S. 2005. Mesozooplankton assemblages in two different bays in the Beagle Channel (Argentina) during January, 2001. Sci. mar., 69 (Suppl. 2):27-37.

Gil, M.; Amín, O.; Torres, A. I. \& Esteves, J. L. 2006. Variabilidad de la calidad de agua del sistema Bahía Ushuaia- Bahía Golondrina (BU-BG), Tierra del Fuego. In: VI Jornadas Nacionales de Ciencias del Mar and XIV Coloquio Argentino de Oceanografía, Puerto Madryn Argentina, December 04 $4^{\text {th }}-8^{\text {th }}$. Abstract Book, p. 206.

Heron, G. A. \& Bowman, T. E. 1971. Postnaupliar developmental stages of the copepod crustaceans Clausocalanus laticeps, C. brevipes, and Ctenocalanus citer (Calanoida: Pseudocalanidae). In: G. U. Llano and I. E. Wallen, eds. Biology of the Antartic seas, IV. Union Am. Geophys., 17:141-165.

Hoffmeyer, M. S. 1983. Zooplancton del área interna de la Bahía Blanca (Buenos Aires, Argentina). I- Composición faunística. Hist. nat., 3(8):73-94.

Hoffmeyer, M. S. 1994. Seasonal succession of Copepoda in the Bahía Blanca estuary. Hydrobiologia, 292/293:303308.

Hoffmeyer, M. S. 2004. Decadal change in zooplankton seasonal sucession in the Bahía Blanca Estuary, Argentina, following introduction of two zooplankton species. J. Plankt. Res., 26(2):1-9.

Hulsemann, K. 1991. The copepodid stages of Drepanopus forcipatus Giesbrecht, with notes on the genus and a comparison with others members of the family Clausocalanidae (Copepoda Calanoida).Helgoländer Meeresunters., 45:199-224.

Isla, F.; Bujalesky, G. \& Coronato, A. 1999. Procesos estuarinos en el canal Beagle, Tierra del Fuego. Revta. Asoc. Geol. Arg., 54(4):307-318.
Kofoid, C. \& Campbell, A. 1929. A conspectus of the marine and freshwater ciliate belonging to the suborder Tintinnoinea, with descriptions of the new species principally from the Agassiz expedition to the Eastern Tropical Pacific, 1904-1905. Univ. Calif. Publs. Zool., 34:1-403.

Lang, K. 1975. Monographie der Harpacticiden.. Stockholm, O. Koeltz Sc. Publers. ed. 2 v. 1682 p.

Lovrich, G. A. 1999. Seasonality of larvae of Brachyura and Anomura (Crustacea decapoda) in the Beagle Channel, Argentina. Sci. mar., 63 (Supl 1):347-354.

Maeda, M. \& Carey., P. 1985. An illustrated guide to the species of the family Strombidiidae (Oligotrichida, Ciliophora), free swimming Protozoa common in the aquatic environment. Bull. Ocean Res. Inst. Univ. Tokyo, 19:1-68.

Mazzocchi, M. G.; Zagami, G.; Ianora, A.; Guglielmo, L.; Crescenti, N. \& Hure, J. 1995. Copepods. In: Guglielmo, L. \& Ianora, A., eds. Atlas of marine zooplankton, Strait of Magellan. Berlín: Springer Verlag. p. 1-279.

Miller, C. B. 1983. The zooplankton of estuaries. In: Ketchum, B.K., ed. Estuaries and enclosd seas. Amsterdam: Elsevier Scientific Publish. Co. p. 103-149.

Pallares, R. 1968. Copépodos Marinos de la Ría Deseado (Santa Cruz, Argentina). Contr.Sistemática- ecológica. Serv. Hidr. Naval, H. 1024:1-125.

Pettigrosso, R.; Barría de Cao, M. S. \& Popovich, C. A. 1997. Planktonic ciliates during a diatom bloom in Bahía Blanca Estuary, Argentina. I. Aloricate ciliates 1. Oebalia, 23:3-19.

Sabatini, M. E.; Giménez, J. \& Rocco, V. 2001. Características del zooplankton del área costera de la plataforma patagónica austral (Argentina). Bolm Inst. Esp. Oceanogr., 17(3-4): 7-13.

Thatje, S.; Schnack-Schiel, S. \& Arntz, W. E. 2003. Developmental trade-offs in Subantartic meroplankton communities and the enigma of low decapod diversity in high Southern latitudes. Mar. Ecol. Prog. Ser., 260:195207.

Sources of Unpublished Material

Amín, A. O. 1995. Toxicidad para invertebrados marinos de algunos metales pesados detectados en las zona costera próxima a Ushuaia, Tierra del Fuego. Tesis doctoral. Facultad de Ciencias Exactas y Naturales. Universidad de Buenos Aires. Buenos Aires. Argentina.

Comoglio, L. I. 1994. La nutrición de los crustáceos decápodos en el Canal Beagle, con especial énfasis en la Centolla (Lithodes santilla) y el centollón (Paralomis granulosa), y la función trófica de los mismos en el ecosistema.Tesis doctoral. Facultad de Ciencias Exactas y Naturales. Universidad de Buenos Aires. Buenos Aires, Argentina.

(Manuscript received 16 December 2005; revised 11 November 2006; accepted 23 February 2007) 